\title{
Pengaruh Konflik Pekerjaan-Keluarga dan Komitmen Organisasional terhadap Turnover Intention pada Hotel Bambu Indah Gianyar
}

\author{
I Wayan Widiantara dan Anak Agung Media Martadiani \\ Fakultas Ekonomi dan Bisnis Universitas Warmadewa, Denpasar-Bali, Indonesia \\ media.marta@gmail.com
}

How to cite (in APA style):

Widiantara, I. W., \& Martadiani, A. A. M. (2020). Pengaruh Konflik Pekerjaan-Keluarga dan Komitmen Organisasional terhadap Turnover Intention pada Hotel Bambu Indah Gianyar. Wacana Ekonomi (Jurnal Ekonomi, Bisnis dan Akuntansi). 19(2), pp.123-130. https://doi.org/10.22225/we.19.2.1954.123-130

\begin{abstract}
Turnover Intention is the intention that comes from within oneself to move from an old job and look for a workplace that feels better than the old work place. The main problem in this study is that there are problems regarding turnover intention in employees who are contrary to the three indicators of turnover intention, such as there are still employees who are thinking of leaving the company, employees are still eager to find other job openings, and employees who are thinking of leaving organization in the coming months. The number of research samples is 80 respondents. The method used is proportional random sampling. The results of this study conclude that work-family conflict and organizational commitment through partial testing have a significant effect on turnover intention in the Hotel Bambu Indah Gianyar. Meanwhile the results of the simultaneous test found that family work conflict and organizational commitment together have a significant influence on turnover intention at the Hotel Bambu Indah Gianyar. The most dominant variable whose influence is work-family conflict. Turnover will increase if influenced by both of these variables
\end{abstract}

Keywords: Family Work Conflict; Organizational Commitment; Turnover Intention.

\begin{abstract}
Abstrak
Turnover Intention adalah niat yang berasal dari dalam dirisendiri untuk berpindah dari pekerjaan yang lama dan mencari tempat kerja yang dirasakan lebih baik dari tempat kerja yang lama. Pokok permasalahan dalam penelitian ini adalah terdapat masalah mengenai turnover intention pada karyawan yang bertolak belakang dengan ketiga indikator dari turnover intention, seperti masih terdapat karyawan yang berpikir untuk pergi dari perusahaan, karyawan masih berkeinginan untuk mencari lowongan pekerjaan lain, dan karyawan yang berpikiran untuk keluar dari organisasi beberapa bulan mendatang. Jumlah sampel penelitian sebesar 80 responden. Metode yang digunakan proposional random sampling. Hasil dari penelitian ini menyimpulkan bahwasannya konflik pekerjaan-keluarga dan komitmen organisasional melalui uji secara parsial mempunyai pengaruh signifikan terhadap turnover intention pada Hotel Bambu Indah Gianyar. Sementara itu hasil uji simultan didapatkan bahwa konflik pekerjaan-keluarga dan komitmen organisasional secara bersama-sama mempunyai pengaruh signifikan terhadap turnover intention pada Hotel Bambu Indah Gianyar. Variable yang paling dominan pengaruhnya adalah konflik pekerjaan-keluarga. Turnover akan meningkat bila dipengaruhi oleh kedua variabel tersebut.
\end{abstract}

Kata Kunci: Konflik Pekerjaan-Keluarga; Komitmen Organisasional; Turnover intention.

\section{PENDAHULUAN}

Sektor pariwisata merupakan sektor yang potensial untuk dikembangkan sebagai salah satu sumber pendapatan daerah. Program pengembangan dan pendayagunaan sumber daya dan potensi pariwisata daerah diharapkan dapat memberikan sumbangan bagi pembangunan ekonomi. Perkembangan industri tersebut tidak hanya berdampak pada peningkatan penerimaan devisa, namun juga telah mampu memperluas kesempatan berusaha dan menciptakan lapangan pekerjaan baru bagi masyarakat dalam mengatasi pengangguran di daerah. Hotel merupakan industri yang bergerak pada bidang pelayanan jasa. Salah satu industri yang menjadikan karyawan sebagai aset perusahaan adalah industri perhotelan. Bali sebagai salah satu tempat destinasi wisata yang terkenal di Indonesia. Keunikan budaya yang kental dan keindahan alam yang dimiliki Bali menjadi daya tarik bagi para wisatawan mancanegara maupun lokal untuk berkunjung ke Bali. Banyaknya wisatawan yang 
berkunjung membuat bisnis industri perhotelan banyak berkembang di Bali. Industri perhotelan yang berkembang di Bali sangat beragam, dari hotel bintang lima hingga hotel melati. Hotel Bambu Indah berlokasi di J1. Baung, Sayan, Gianyar Bali. Hotel Bambu Indah Bali berdiri pada tahun 2007 dalam perjalanannya dari tahun ke tahun hotel ini selalu melayani para tamunya dengan baik dan ramah. Tetapi sangat disayangkan pada Bambu Indah Bali terdapat permasalahan terkait dengan turnover intention pada hotel tersebut.

Keinginan untuk keluar dapat dipengaruhi dua faktor yaitu faktor organisasi dan faktor individu. Faktor organisasi yang dapat menyebabkan turnover intention antara lain gaji, pekerjaan yang berat, jam kerja yang tidak fleksibel serta lingkungan kerja yang tidak mendukung. Faktor individu yang dapat menyebabkan turnover intention berupa konflik keluarga-pekerjaan, stres kerja, rendahnya kepuasan kerja dan komitmen organisasional (Riley, 2006). Begitu banyaknya faktor yang melatarbelakangi turnover intention di dalam perusahaan, maka penelitian ini memfokuskan pada faktor komitmen organisasional dan konflik pekerjaan-keluarga. Selain faktor komitmen organisasional, faktor yang dapat berpengaruh pada turnover intention yaitu konflik pekerjaankeluarga. Konflik pekerjaan-keluarga (work family conflict) yang terjadi pada individu akibat menanggung peran ganda baik dalam pekerjaan (work) maupun keluarga (family) (Rantika \& Sunjoyo, 2010).

Tabel 1

Jumlah Turnover Karyawan Bambu Indah Tahun 2015 - 2018

\begin{tabular}{|c|c|c|c|c|c|}
\hline \multirow[b]{2}{*}{ Tahun } & \multirow{2}{*}{$\begin{array}{c}\text { Jumlah } \\
\text { karyawan } \\
\text { awal tahun } \\
\text { (1) }\end{array}$} & \multirow{2}{*}{$\begin{array}{c}\text { Jumlah } \\
\text { karyawan } \\
\text { akhir tahun } \\
\text { (2) }\end{array}$} & \multicolumn{2}{|c|}{ Jumlah Karyawan } & \multirow{2}{*}{$\begin{array}{c}\text { Turnover } \\
\frac{4}{(1)+(2): 2} \times 100 \%\end{array}$} \\
\hline & & & $\begin{array}{c}\text { Masuk } \\
\text { (3) }\end{array}$ & $\begin{array}{c}\text { Keluar } \\
(4)\end{array}$ & \\
\hline 2015 & 76 & 75 & 5 & 6 & 7,94 \\
\hline 2016 & 75 & 79 & 11 & 7 & 9,09 \\
\hline 2017 & 79 & 77 & 5 & 7 & 8,97 \\
\hline 2018 & 77 & 80 & 11 & 8 & 10,19 \\
\hline
\end{tabular}

Sumber : HRD Hotel bambu Indah, 2019

Berdasarkan rumus turnover oleh (Hasibuan, 2012) dapat dilihat dari data diatas bahwa terjadi tingkat turnover yang cukup tinggi pada karyawan Bambu Indah Gianyar. Turnover tertinggi terjadi pada tahun 2018 dengan persentase turnover yang terjadi sebanyak 10,19 persen karyawan yang memilih untuk keluar dari Bambu Indah Gianyar. Turnover dikatakan normal berkisar antara 5-10\% pertahun dan dikatakan tinggi apabila lebih besar dari $10 \%$ pertahun (Gillies, 1989).

Berdasarkan latar belakang diatas penelitian ini dilakukan untuk menganalisis pengaruh antara Konflik Pekerjaan-Keluarga Terhadap Turnover Intention, pengaruh Komitmen Organisasional Terhadap Turnover Intention dan pengaruh Konflik Pekerjaan-Keluarga dan komitmen Organisasional Terhadap Turnover Intention Pada Hotel Bambu Indah Gianyar.

Tujuan penelitian ini adalah: (1) Untuk menganalisis pengaruh konflik pekerjaan-keluarga terhadap turnover intention pada Hotel Bambu Indah Gianyar. (2) Untuk menganalisis pengaruh komitmen organisasional terhadap turnover intention pada Hotel Bambu Indah Gianyar. (3) Untuk menganalisis pengaruh konflik pekerjaan keluarga dan komitmen organisasional terhadap turnover intention pada Hotel Bambu Indah Gianyar.

\section{TINJAUAN PUSTAKA}

\section{Turnover Intention}

Turnover intention merupakan suatu bentuk dari karyawan untuk menarik diri pada dunia kerja dan karyawan tersebut juga memiliki hak untuk menentukan apakah tetap bekerja atau mengundurkan diri dari suatu perusahaan (Sidharta \& Margaretha, 2011). Pendapat lainnya oleh (Ucho, Mkavga, \& Onyishi, 2012) menyatakan Turnover intention adalah keinginan berpindah kerja sebagai hasrat keinginan untuk mencari peluang pekerjaan alternatif di perusahaan lainnya.

Berdasarkan definisi dan penjelasan diatas dapat dinyatakan bahwa turnover intention merupakan niat atau keinginan dari diri sendiri untuk berpindah dari tempat pekerjaan yang lama dan 
mencari pekerjaan yang dirasakan lebih baik dari pekerjaan sebelumnya.

Faktor-faktor yang mempengaruhi terjadinya Turnover Intention sebagai berikut (Hartono \& Setiawan, 2018):

- Usia

- Lama Kerja

- Tingkat Pendidikan dan Intelegensi

- Keterikatan Terhadap Perusahaan

Pendapat lainnya oleh (Kumar, Ramendran, \& Yacob, 2012) mengemukakan bahwa tunover intentions diklasifikasikan menjadi tiga bagian yaitu:

- Turnover yang tidak dapat dicegah yaitu keluarnya seorang karyawan yang disebabkan oleh penyakit, masalah keluarga atau pensiun.

- Turnover intention yang diinginkan yaitu keluarnya seorang karyawan karena ketidak mampuan karyawan dalam melaksanakan tugas yang diberikan.

- Turnover intention yang tidak diinginkan yaitu melingkupi komponen dan kualitas karya wan yang meninggalkan pekerjaan mereka karena masalah organisasi seperti rendahnya dukungan dari organisasi dan adanya konflik didalam organisasi.

Adapun, indikator untuk mengukur turnover intention adalah sebagai berikut (Jehanzeb, Rasheed, \& Rasheed, 2013):

- Pikiran untuk keluar

- Keinginan untuk mencari lowongan pekerjaan lain

- Adanya keinginan untuk meninggalkan organisasi dalam beberapa bulan mendatang.

\section{Komitmen Organisasional}

Komitmen adalah kesepakatan antara beberapa individu di dalamnya yang bersifat mengikat dan mengarah pada keseluruhan (Sidharta \& Margaretha, 2011). Komitmen organisasional dapat digambarkan sebagai kekuatan yang memikat individu untuk suatu tindakan yang relevan dengan tujuan dan sasaran organisasi yang memperkerjakan (Madhuri, Srivastava, \& Srivastava, 2014). Ada empat faktor yang mempengaruhi komitmen organisasional sendiri diantaranya (Kreitner \& Angelo, 2014):

- Faktor pribadi

- Faktor yang berkaitan dengan peran seperti ambiguitas peran dan konflik peran berkorelasi negatif dengan komitmen organisasi.

- Pengalaman kerja

- Faktor Budaya

\section{Konflik Pekerjaan-Keluarga}

Konflik Pekerjaan-Keluarga merupakan peran dua arah yang dimaksud adalah adanya tuntutan antara pekerjaan mengganggu tuntutan keluarga, misalnya tanggung jawab karyawan terhadap keluarga menjadi terganggu dengan adanya tanggung jawab yang berhubung dengan pekerjaan yang menyebabkan hasil yang tidak diinginkan contohnya stress, kesehatan yang memburuk, konflik yang berhubungan dengan pekerjaan, ketidak hadiran hingga turnover (Ghayyur \& Jamal, 2012). Konflik pekerjaan-keluarga terjadi biasanya pada karyawan yang memiliki jam kerja yang padat, sehingga waktu yang harusnya diluangkan untuk keluarga menjadi terbatas. Terdapat tiga jenis konflik pekerjaan-keluarga, yaitu :

\section{- Time-based conflict}

Time-based conflict adalah waktu yang dibutuhkan seseorang untuk melakukan salah satu tuntutan baik itu peran dari keluarga atau pekerjaan yang nantinya akan mengurangi waktu yang dibutuhkan untuk melakukan tuntutan lain.

\section{- Strain-based conflict} lainnya.

Strain-based conflict yaitukonflik yang terjadi pada saat tekanan dari salah satu peran yang

- Behavior-based Conflict 
Behavior-based Conflict berhubungan dengan ketidak sesuaian antara pola perilaku dengan yang diinginkan oleh kedua bagian (pekerjaan atau keluarga).

\section{Hipotesis}

H1 : Ada pengaruh positif dan signifikan Konflik pekerjaan-keluarga terhadap turnover intention

H2 : Ada pengaruh negatif Komitmen Organisasional terhadap Turnover Intention.

H3 : Ada pengaruh dan signifikan Konflik pekerjaan keluarga dan komitmen organisasional terhadap turnover intention, konflik pekerjaan keluarga mempunyai pengaruh yang dominan terhadap turnover intention.

\section{METODE}

Populasi dalam penelitian ini adalah seluruh karyawan pada Bambu Indah Gianyar yang terdiri dari karyawan tetap yang berjumlah 80 karyawan. Uji instrumen dalam penelitian ini menggunakan 2 jenis uji instrumen yaitu uji validitas yang dikatakan valid jika pertanyaan kuisioner mampu untuk mengungkapkan suatu yang diukur oleh kuisioner tersebut. setiap kuisioner dinyatakan valid bila nilai dari koefisien kolerasi $\geq 0.30$. Kedua adalah uji reliabilitas yang apabila digunakan beberapa kali untuk mengukur objek yang sama akan menghasilkan data yang sama. Pengukuran reliabilitas dilakukan dengan menggunakan program SPSS, dengan cara menghitung besarnya cronbach's alpha apabila melebihi 0,60 maka instrument dapat dikatakan reliable.

Analisis data dalam penelitian ini menggunakan 5 jenis uji yang dijabarkan sebagai berikut:

\section{Uji Asumsi Klasik}

\section{Uji Normalitas}

Uji normalitas bertujuan untuk menguji apakah distribusi data mengikuti atau mendekati distribusi normal. Data yang baik adalah data yang pola distribusinya normal. Uji statistik yang digunakan untuk uji normalitas data dalam penelitian ini adalah uji kolmogrov-smirnov. Dasar pengambilan keputusan dari uji normalitas ini adalah dengan melihat probality asymp. Sig (2-tailed). Jika nilai probality asymp.sig yang dihasilkan $>0,05$ maka data berdistribusi normal.

\section{Uji Multikolinieritas}

Uji Multikolinearitas adalah kejadian yang menginformasikan terjadinya hubungan antara variabel bebas (X). Jika tidak terjadi korelasi dari variabel bebas maka tidak terdapat masalah pada multikolinearitas varian. Untuk mendeteksi adanya multikolinearitas dapat dilihat melalui nilai variance inflationfactor (VIF). Jika nilai VIF $<10$ dan tolerance $>0,1$ maka variabel dapat dikatakan bebasmultikolinearitas.

\section{Uji Heteroskedastisitas}

Uji heterokedastisitas bertujuan untuk menguji apakah dalam sebuah model regresi terjadi ketidaksamaan varian dari residual satu pengamatan ke pengamatan yang lain. Untuk melihat ada atau tidaknya heterokedastisitas dalam suatu varian error term (et) suatu model regresi adalah dengan menggunakan metode uji Glejser. Suatu model dikatakan baik jika tidak terjadi heterokedastisitas. Jika nilai sig $<\alpha 0.05$ maka pada varian terdapat heterokedastisitas. Jika nilai sig $>\alpha 0.05$ maka pada varian tidak terdapat heterokedastisitas.

\section{Analisis Regresi Linier Berganda}

Analisis Regresi Linear Berganda bertujuan untuk menjelaskan pengaruh variabel bebas dan variabel terikat. Variabel bebas yang mempengaruhi di dalam penelitian ini yaitu variabel konflik pekerjaan-keluarga $\left(\mathrm{X}_{1}\right)$ dan komitmen organisasional $\left(\mathrm{X}_{2}\right)$, sedangkan variabel terikat yang dipengaruhi di dalam penelitian ini adalah turnover intention $(\mathrm{Y})$.

\section{Uji Signifikan Simultan (Uji Statistik F)}

Uji $\mathrm{F}$ digunakan untuk mengambil apakah variabel bebas secara bersama-sama berpengaruh signifikan terhadap variabel terikat. Apabila hasil dari uji $\mathrm{F}$ menyatakan signifikan $\mathrm{F}$ atau ${ }_{P}$ value $\leq$ 0,05 maka hubungan antar variabel- variabel bebas adalah signifikan mempengaruhi variabel terikat 
dan model regresi yang digunakan dianggap layak diuji.

\section{Uji Signifikan Parsial (Uji Statistik t)}

Uji hipotesis terkait pengaruh konflik pekerjaan-keluarga dan komitmen organisasional terhadap turnover intention dilakukan dengan menggunakan uji $\mathrm{t}(t$-test). Koefisien variabel bebas dapat dilihat pada kolom unstandardized coefficients (Ghozali, 2016).

\section{Analisis koefisien Beta (Beta Coefficients)}

Untuk menentukan kekuatan masing-masing variabel bebas dalam menentukan variabel bebas (independent variabel) yang paling mempengaruhi nilai variabel terikat (dependent variabel) dalam suatu model regresi linier, maka digunakan koefisien beta.

\section{HASIL DAN PEMBAHASAN}

Responden yang dijadikan sampel dalam penelitian ini adalah pegawai Hotel Bambu Indah Gianyar yang berjumlah 80 responden.

Tabel 2

Rekapitulasi Hasil Uji Validitas dan Reliabilitas Instrumen Penelitian

\begin{tabular}{|c|c|c|c|c|c|c|}
\hline \multirow[b]{2}{*}{ No } & \multirow[b]{2}{*}{ Variabel } & \multirow{2}{*}{$\begin{array}{c}\text { Item } \\
\text { Pertanyaan }\end{array}$} & \multicolumn{2}{|c|}{ Validitas } & \multicolumn{2}{|c|}{ Reliabilitas } \\
\hline & & & $\begin{array}{c}\text { Koefisien } \\
\text { Korelasi }\end{array}$ & Keterangan & $\begin{array}{c}\text { Alpha } \\
\text { Cronbach }\end{array}$ & Keterangan \\
\hline 1 & $\begin{array}{l}\text { Konflik Pekerjaan } \\
\text { Keluarga }\left(\mathrm{X}_{1}\right)\end{array}$ & $\begin{array}{l}\mathrm{X}_{1.1} \\
\mathrm{X}_{1.2} \\
\mathrm{X}_{1.3}\end{array}$ & $\begin{array}{l}0,825 \\
0,926 \\
0,822\end{array}$ & $\begin{array}{l}\text { Valid } \\
\text { Valid } \\
\text { Valid }\end{array}$ & 0,821 & Reliabel \\
\hline 2 & $\begin{array}{c}\text { Komitmen } \\
\text { Organisasional }\left(\mathrm{X}_{2}\right)\end{array}$ & $\begin{array}{l}\mathrm{X}_{2.1} \\
\mathrm{X}_{2.2} \\
\mathrm{X}_{2.3}\end{array}$ & $\begin{array}{l}0,802 \\
0,816 \\
0,866\end{array}$ & $\begin{array}{l}\text { Valid } \\
\text { Valid } \\
\text { Valid }\end{array}$ & 0,774 & Reliabel \\
\hline 3 & Turnover Intention (Y) & $\begin{array}{l}Y_{1.1} \\
Y_{1.2} \\
Y_{1.3}\end{array}$ & $\begin{array}{l}0,915 \\
0,752 \\
0,842\end{array}$ & $\begin{array}{l}\text { Valid } \\
\text { Valid } \\
\text { Valid }\end{array}$ & 0,788 & Reliabel \\
\hline
\end{tabular}

Tabel 3

Hasil Uji Analisis Regresi Linier Berganda

Coefficients $^{\mathrm{a}}$

\begin{tabular}{|c|c|c|c|c|c|c|}
\hline \multirow{2}{*}{\multicolumn{2}{|c|}{ Model }} & \multicolumn{2}{|c|}{ Unstandardized Coefficients } & \multirow{2}{*}{$\begin{array}{c}\begin{array}{c}\text { Standardized } \\
\text { Coefficients }\end{array} \\
\text { Beta }\end{array}$} & \multirow[b]{2}{*}{$t$} & \multirow[b]{2}{*}{ Sig. } \\
\hline & & $\mathrm{B}$ & Std. Error & & & \\
\hline \multirow[t]{3}{*}{1} & (Constant) & 5.777 & 2.099 & & 2.752 & .007 \\
\hline & $\begin{array}{l}\text { Konflik Pekerjaan- } \\
\text { Keluarga }\end{array}$ & .915 & .111 & .753 & 8.265 & .000 \\
\hline & $\begin{array}{l}\text { Komitmen } \\
\text { Organisasional }\end{array}$ & -.391 & .173 & -.207 & -2.266 & .026 \\
\hline
\end{tabular}

a. Dependent Variable: Turnover Intention berikut:

Berdasarkan Tabel 3 diperoleh nilai konstanta (a) dan koefisien regresi (b1) dan (b2) sebagai $\mathrm{a}=5,777$

$$
\begin{array}{ll}
\text { b1 } & =0,915 \\
\text { b2 } & =-0,391
\end{array}
$$

Berdasarkan nilai-nilai tersebut di atas, maka diperoleh persamaan regresi linear berganda sebagai berikut:

$\mathrm{Y}=\alpha+\mathrm{b}_{1} \mathrm{X}_{1}+\mathrm{b}_{2} \mathrm{X}_{2}+e$

$\mathrm{Y}=5,777+0,915 \mathrm{X}_{1}-0,391 \mathrm{X}_{2}$

Dari persamaan tersebut di atas, dapat diartikan sebagai berikut:

Nilai constant 5,777 menunjukkan bahwa apabila nilai dari konflik pekerjaan keluarga $\left(\mathrm{X}_{1}\right)$ dan komitmen organisasional $\left(\mathrm{X}_{2}\right)$ sama-sama nol $(0)$, maka turnover intention $(\mathrm{Y})$ pada Hotel Bambu 


\begin{abstract}
Indah Gianyar akan meningkat sebesar 5,777 satuan.
$\mathrm{X}_{1}=+0,915$ menunjukkan bahwa konflik pekerjaan keluarga $\left(\mathrm{X}_{1}\right)$ berpengaruh positif terhadap turnover intention $(\mathrm{Y})$ pada Hotel Bambu Indah Gianyar.

$\mathrm{X}_{2}=-0,210$ menunjukkan bahwa komitmen organisasional $\left(\mathrm{X}_{2}\right)$ berpengaruh negatif terhadap turnover intention $(\mathrm{Y})$ pada Hotel Bambu Indah Gianyar.
\end{abstract}

\title{
Pengaruh Konflik Pekerjaan-Keluarga Terhadap Turnover Intention
}

Hasil pengujian t-test pengaruh konflik pekerjaan keluarga terhadap turnover intention pada Hotel Bambu Indah Gianyar diperoleh nilai koefisien regresi sebesar 0,915 dan menunjukkan nilai $\mathrm{t}_{\text {hitung }}$ sebesar 8,265 serta nilai signifikan uji $\mathrm{t}$ sebesar 0,000 yang lebih kecil dari $\alpha$ (taraf nyata) $=$ 0,05 , maka dapat disimpulkan bahwa konflik pekerjaan keluarga $\left(\mathrm{X}_{1}\right)$ berpengaruh positif dan signifikan terhadap turnover intention (Y) pada Hotel Bambu Indah Gianyar.

Hal ini menunjukkan sebuah pengaruh yang positif, jadi semakin meningkat konflik pekerjaan keluarga yang ada pada Hotel Bambu Indah Gianyar maka turnover intention akan semakin meningkat. Konflik pekerjaan-keluarga merupakan satu hal yang tidak dapat dihindari oleh seorang karyawan. Konflik ini terjadi ketika adanya dua permasalahan tuntutan antara lain tuntutan yang berasal dari dalam keluarga dan tuntutan yang berasal dari pekerjaaan

\section{Pengaruh Komitmen Organisasional Terhadap Turnover intention}

Hasil pengujian t-test pengaruh komitmen organisasional secara parsialberpengaruh negatif dan signifikan terhadap turnover intention pada Hotel Bambu Indah Gianyar diperoleh nilai koefisien regresi sebesar $-0,391$ dan menunjukkan nilai $t_{\text {hitung }}$ sebesar $-2,266$ serta nilai signifikan uji $\mathrm{t}$ sebesar 0,026 yang lebih kecil dari $\alpha$ (taraf nyata) $=0,05$, maka dapat disimpulkan bahwa komitmen organisasional $\left(\mathrm{X}_{2}\right)$ berpengaruh negatif dan signifikan terhadap turnover intention $(\mathrm{Y})$ pada Hotel Bambu Indah Gianyar.

Hal ini menunjukkan sebuah pengaruh yang negatif, jadi semakin menurun komitmen organisasional karyawan pada Hotel Bambu Indah Gianyar maka turnover intention akan semakin meningkat.Pernyataan ini sejalan dengan temuan penelitian (Wateknya, 2016) Menunjukkan bahwa pengaruh Komitmen Organisasional berpengaruh negatif terhadap Turnover Intention. Komitmen Organisasional memiliki dampak negatif yang signifikanterhadap Turnover Intention karyawan (Widyadmono, 2015).

\section{Pengaruh Konflik Pekerjaan-Keluarga Dan Komitmen Organisasional Terhadap Turnover Intention}

Hasil pengujian simultan pengaruh konflik pekerjaan-keluarga dan komitmen organisasional terhadap turnover intention pada Hotel Bambu Indah Gianyardiperoleh nilai $F_{\text {hitung }}$ sebesar 35,137 dengan nilai signifikansi $\mathrm{P}_{\text {value }} 0,000$ yang lebih kecil dari $\alpha=0,05$, hal ini berarti model dapat digunakan untuk analisa lebih lanjut atau dengan kata lain ada pengaruh secara simultan dari variabel konflik pekerjaan keluarga dan komitmen organisasional terhadap turnover intention pada Hotel Bambu Indah Gianyar.

Hasil ini memberikan makna bahwa seluruh variabel independen mampu memprediksi atau menjelaskan fenomena turnover intention pada Hotel Bambu Indah Gianyar. Hasil penelitian ini sejalan dengan hasil penelitian sebelumnya yang dilakukan (Apriliyana, 2017) menunjukkan bahwa konflik pekerjaan keluarga dan komitmen organisasional berpengaruh dan signifikan terhadap turnover intention.

\section{SIMPULAN}

Berdasarkan hasil penelitian yang telah diuraikan, maka simpulan yang berkaitan dengan pengaruh konflik pekerjaan keluarga dan komitmen organisasional terhadap turnover intention pada Hotel Bambu Indah Gianyar pada penelitian ini adalah sebagai berikut:

- Konfik Pekerjaan-Keluarga berpengaruh positif dan signifikan terhadap Turnover Intention pada Hotel Bambu Indah Gianyar.

- Komitmen Organisasional berpengaruh negative dan signifikan terhadap Turnover Intention pada Hotel Bambu Indah Gianyar

- Konflik Pekerjaan-Keluarga dan Komitmen Organisasional berpengaruh secara simultan terhadap 
Turnover Intentionpada Hotel Bambu Indah Gianyar.

\section{DAFTAR PUSTAKA}

Apriliyana, R. (2017). Pengaruh Komitmen, Kompensasi, Dan Konflik Terhadap Turnover Intention Karyawan (Studi Kasus di UMKM Bakpia Paguyuban PEW Laris Manis). Universitas PGRI Yogyakarta. Retrieved from http://repository.upy.ac.id/id/eprint/1382

Ghayyur, M., \& Jamal, W. (2012). Work-Family Conflicts: A Case of Employees' Turnover Intention. International Journal of Social Science and Humanity, 2(3), 168-174. Retrieved from http:// www.ijssh.org/papers/90-CH007.pdf

Ghozali, I. (2016). Aplikasi Analisis Multivariete dengan Program IBM SPSS 23 Edisi 8. Semarang: Badan Penerbit Universitas Diponegoro.

Gillies, D. A. (1989). Manajemen Keperawatan: Suatu Pendekatan Sistem Edisi Kedua (A lih Bahasa: Dika Sukmana dkk). Illioni: WB Saunders Company.

Hartono, Y. M., \& Setiawan, R. (2018). Pengaruh Work Family Conflict Dan Compensation Terhadap Turnover Intention Pada Gold's Gym Sutos Surabaya. Agora, 6(2). Retrieved from http:// publication.petra.ac.id/index.php/manajemen-bisnis/article/view/7792

Hasibuan, M. S. P. (2012). Manajemen Sumber Daya Manusia. Jakarta: Bumi Aksara.

Jehanzeb, K., Rasheed, A., \& Rasheed, M. (2013). Organizational Commitment and Turnover Intentions: Impact of Employee's Training in Private Sector of Saudi Arabia. International Journal of Business and Management, 8(8), 79-90. Retrieved from https://doi.org/10.5539/ijbm.v8n8p79

Kreitner, R., \& Angelo, K. (2014). Perilaku Organisasi. Jakarta: Salemba Empat. Retrieved from http:// lib.ui.ac.id/detail.jsp?id=20399035

Kumar, R., Ramendran, C., \& Yacob, P. (2012). A Study on Turnover Intention in Fast Food Industry: Employees' Fit to the Organizational Culture and the Important of their Commitment. International Journal of Academic Research in Business and Social Sciences, 2(5), 9-42. Retrieved from https:// www.semanticscholar.org/paper/A-Study-on-Turnover-Intention-in-Fast-Food-IndustryKumar/6f802d91022714a54170bdb00fa9e17fc7c11692

Madhuri, K., Srivastava, P., \& Srivastava, P. (2014). The Effect Of Organizational Commitment, And Job Satisfaction, On Employee's Job Performance. International Journal of Technical Research and Applications, 2(4), 215-217. Retrieved from https:// pdfs.semanticscholar.org/8347/424b30e97368a12155f74c48254f33a0bf18.pdf

Rantika, R., \& Sunjoyo. (2010). Pengaruh Konflik Kerja-keluarga terhadap Komitmen Organisasional yang Dimediasi oleh Kepuasan Kerja pada Profesi Perawat di Rumah Sakit Umum Daerah (RSUD) Dr. Moewardi Surakarta. In Proceeding of Seminar Akbar Forum Manajemen Indonesia (FMI) (pp. 117). Retrieved from https://pdfs.semanticscholar.org/eb46/ c9cace6aa552e93e3b615d479ddeb12d9e85.pdf

Riley, D. (2006). Turnover Intentions: The Mediation Effects of Job Satisfaction, Affective Commitment and Continuance Commitment. University of Waikato. Retrieved from https:// researchcommons.waikato.ac.nz/handle/10289/2415

Sidharta, N., \& Margaretha, M. (2011). Dampak Komitmen Organisasi Dan Kepuasan Kerja Terhadap Turnover Intention: Studi Empiris Pada Karyawan Bagian Operator Di Salah Satu Perusahaan Garment Di Cimahi. Jurnal Manajemen Maranatha, 10(2), 129-142. Retrieved from https:// www.neliti.com/id/publications/114529/dampak-komitmen-organisasi-dan-kepuasan-kerja-terhadapturnover-intention-studi

Ucho, A., Mkavga, T., \& Onyishi, I. E. (2012). Job Satisfaction, Gender, Tenure, and Turnover Intentions 
among Civil Servants in Benue State. Interdisciplinary Journal of Contemporary Research in Business, 3(11). Retrieved from http://connection.ebscohost.com/c/articles/77243869/jobsatisfaction-gender-tenure-turnover-intentions-among-civil-servants-benue-state

Wateknya, Y. (2016). Pengaruh Komitmen Organisasi Dan Kepuasan Kerja Terhadap Turnover Intention (Studi Kasus pada Karyawan PT. Kharisma Rotan Mandiri). Fakultas Ekonomi Universitas Negeri Yogyakarta. Retrieved from http://eprints.uny.ac.id/38884/1/YogaWateknya_12808144030.pdf

Widyadmono, M. (2015). Pengaruh Kepuasan Kerja Dan Komitmen Organisasi Terhadap Turnover Intention. Jurnal Manajemen Indonesia, 15(2), 157-168. Retrieved from https://oi.org/10.25124/ jmi.v15i2.711 